\title{
Vitamin D and mortality: meta-analysis of individual participant data from a large consortium of cohort studies from Europe and the United States
}

\author{
(9) (1) $\Theta$ OPEN ACCESS
}

Ben Schöttker postdoctoral scientist ${ }^{1}$, Rolf Jorde professor ${ }^{23}$, Anne Peasey postdoctoral scientist ${ }^{4}$, Barbara Thorand senior researcher in epidemiology ${ }^{5}$, Eugène $\mathrm{H} \mathrm{J} \mathrm{M} \mathrm{Jansen} \mathrm{postdoctoral} \mathrm{scientist}{ }^{6}$, Lisette de Groot professor of nutrition and ageing ${ }^{7}$, Martinette Streppel postdoctoral scientist ${ }^{7}$, Julian Gardiner research associate ${ }^{4}$, José Manuèl Ordóñez-Mena PhD candidate ${ }^{18}$, Laura Perna postdoctoral scientist ${ }^{1}$, Tom Wilsgaard professor $^{9}$, Wolfgang Rathmann senior researcher in epidemiology ${ }^{10}$, Edith Feskens professor ${ }^{7}$, Ellen Kampman professor ${ }^{7}$, Galatios Siganos research associate $^{9}$, Inger Njølstad professor ${ }^{9}$, Ellisiv Bøgeberg Mathiesen professor ${ }^{11}$, Růžena Kubínová senior researcher $^{12}$, Andrzej Pająk professor ${ }^{13}$, Roman Topor-Madry senior researcher ${ }^{13}$, Abdonas Tamosiunas professor ${ }^{14}$, Maria Hughes postdoctoral scientist ${ }^{15}$, Frank Kee professor ${ }^{15}$, Martin Bobak professor ${ }^{4}$, Antonia Trichopoulou professor ${ }^{16}{ }^{17}$, Paolo Boffetta professor ${ }^{16}{ }^{18}$, Hermann Brenner professor ${ }^{1}$, on behalf of the Consortium on Health and Ageing: Network of Cohorts in Europe and the United States (CHANCES)

\footnotetext{
${ }^{1}$ Division of Clinical Epidemiology and Aging Research, German Cancer Research Center, Im Neuenheimer Feld 581, 69120 Heidelberg, Germany; ${ }^{2}$ Troms $\varnothing$ Endocrine Research Group, Department of Clinical Medicine, University of Troms $\varnothing$ (UiT) the Arctic University of Norway, 9037 Troms $\varnothing$, Norway; ${ }^{3}$ Division of Internal Medicine, University Hospital of North Norway, 9038 Troms $\varnothing$, Norway; ${ }^{4}$ Department Epidemiology and Public Health, University College London, London WC1E 6BT, UK; ${ }^{5}$ Institute of Epidemiology II, Helmholtz Zentrum München, German Research Center for Environmental Health, Neuherberg, Germany; ${ }^{6}$ Laboratory for Health Protection Research, National Institute for Public Health and the Environment, 3720 BA Bilthoven, Netherlands; ${ }^{7}$ Division of Human Nutrition, Wageningen University, 6700 EV Wageningen, Netherlands; ${ }^{8}$ Network Aging Research (NAR), University of Heidelberg, Heidelberg, Germany; ${ }^{9}$ Epidemiology of Chronic Diseases Research Group, Department of community medicine, UiT the Arctic University of Norway, 9037 Troms $ø$, Norway; ${ }^{10}$ German Diabetes Center, Institute for Biometrics and Epidemiology, Leibniz Center for Diabetes Research at Heinrich Heine University Düsseldorf, 40225 Düsseldorf, Germany; ${ }^{11}$ Brain and Circulation Research Group, Department of clinical medicine, UiT the Arctic University of Norway, 9037 Tromsø, Norway; ${ }^{12}$ National Institute of Public Health, Prague, Czech Republic;

${ }^{13}$ Jagiellonian University Medical College, Faculty of Health Sciences, Krakow, Poland; ${ }^{14}$ Institute of Cardiology of Lithuanian University of Health Sciences, Kaunas, Lithuania; ${ }^{15}$ UKCRC Centre of Excellence for Public Health, Queens University Belfast, Northern Ireland, UK; ${ }^{16} \mathrm{Hellenic} \mathrm{Health}$ Foundation, Kaisareias 13 \& Alexandroupoleos, Athens 11527, Greece; ${ }^{17}$ University of Athens, Medical School, Department of Hygiene, Epidemiology and Medical Statistics, Mikras Asias 75 st, Athens 11527, Greece; ${ }^{18}$ Institute for Translational Epidemiology and Tisch Cancer Institute, Icahn School of Medicine at Mount Sinai, New York, NY, USA
}

\begin{abstract}
Objective To investigate the association between serum 25-hydroxyvitamin D concentrations $(25(\mathrm{OH}) \mathrm{D})$ and mortality in a large consortium of cohort studies paying particular attention to potential age, sex, season, and country differences.
\end{abstract}

Design Meta-analysis of individual participant data of eight prospective cohort studies from Europe and the US.

Setting General population.

Participants 26018 men and women aged 50-79 years 


\begin{abstract}
Main outcome measures All-cause, cardiovascular, and cancer mortality.
\end{abstract}

Results 25(OH)D concentrations varied strongly by season (higher in summer), country (higher in US and northern Europe) and sex (higher in men), but no consistent trend with age was observed. During follow-up, 6695 study participants died, among whom 2624 died of cardiovascular diseases and 2227 died of cancer. For each cohort and analysis,

$25(\mathrm{OH}) \mathrm{D}$ quintiles were defined with cohort and subgroup specific cut-off values. Comparing bottom versus top quintiles resulted in a pooled risk ratio of 1.57 (95\% Cl 1.36 to 1.81) for all-cause mortality. Risk ratios for cardiovascular mortality were similar in magnitude to that for all-cause mortality in subjects both with and without a history of cardiovascular disease at baseline. With respect to cancer mortality, an association was only observed among subjects with a history of cancer (risk ratio, 1.70 (1.00 to 2.88)). Analyses using all quintiles suggest curvilinear, inverse, dose-response curves for the aforementioned relationships. No strong age, sex, season, or country specific differences were detected. Heterogeneity was low in most meta-analyses.

Conclusions Despite levels of 25(OH)D strongly varying with country, sex, and season, the association between $25(\mathrm{OH}) \mathrm{D}$ level and all-cause and cause-specific mortality was remarkably consistent. Results from a long term randomised controlled trial addressing longevity are being awaited before vitamin $\mathrm{D}$ supplementation can be recommended in most individuals with low $25(\mathrm{OH}) \mathrm{D}$ levels.

\section{Introduction}

Although vitamin D is obtained from diet and dietary supplements, the main source of vitamin $\mathrm{D}$ is its production in skin under the influence of solar ultraviolet $\mathrm{B}$ radiation. The most commonly measured vitamin $\mathrm{D}$ metabolite is serum 25-hydroxyvitamin $\mathrm{D}(25(\mathrm{OH}) \mathrm{D})$ because of its greater half life ( 3 weeks) and up to 1000-fold higher serum levels compared with the physiologically active metabolite

1,25-dihydroxyvitamin D (half life of a few hours). ${ }^{1}$ As ultraviolet $\mathrm{B}$ exposure varies with the latitude of regions and during the year, so mean $25(\mathrm{OH}) \mathrm{D}$ concentrations of populations also vary accordingly. ${ }^{2}$ Furthermore, women are generally more prone to low $25(\mathrm{OH}) \mathrm{D}$ concentrations than men (possibly because of a positive correlation of $25(\mathrm{OH}) \mathrm{D}$ with testosterone levels $),{ }^{4}$ and vitamin D deficiency is especially common among elderly people, who often have less sun exposure (because of reduced outdoor activity) and limited capacity of the skin to produce vitamin D metabolites. ${ }^{5}$ However, it is unclear if and to what extent these influences on production and maintenance of sufficient vitamin D metabolite concentrations affect the prognostic association of low $25(\mathrm{OH}) \mathrm{D}$ concentrations with mortality.

The objective of this meta-analysis of a consortium of eight prospective cohort studies from different European countries and the United States was to investigate the prognostic association of $25(\mathrm{OH}) \mathrm{D}$ measurements with all-cause, cardiovascular, and cancer mortality, paying particular attention to potential differences between countries, sexes, age groups, and seasons of blood draw.

\section{Methods}

This manuscript was written in adherence to the Strengthening The Reporting of Observational Studies in Epidemiology (STROBE) and the Meta-analysis Of Observational Studies in Epidemiology (MOOSE) statements. ${ }^{6}$

\section{Study design and study population}

This investigation is a meta-analysis of individual participant data of seven population based cohorts with measured $25(\mathrm{OH}) \mathrm{D}$ of the Consortium on Health and Ageing: Network of Cohorts in Europe and the United States (CHANCES, www.chancesfp7. eu) together with the third US National Health And Nutrition Examination Survey (NHANES III). The cohorts of the CHANCES consortium were chosen because all variables needed for this project were harmonised according to pre-defined rules. The harmonisation rules were discussed among the CHANCES partners until a consensus was reached. The NHANES survey was added to include a North American cohort and because it has an open access policy that enabled data access with subsequent conversion according to the CHANCES data harmonisation rules. The cohorts cover 16 European countries and the United States. The cohorts' key characteristics are summarised in table $1 \Downarrow$, and the study designs are described in the supplemental data and previous publications. ${ }^{2-12}$ All CHANCES cohorts and the NHANES are conducted in accordance with the declaration of Helsinki, and written informed consent was obtained from all study participants.

\section{Inclusion and exclusion criteria}

To make cohorts more comparable, analyses were restricted to study participants aged 50-79 years. Current smokers were excluded from the Troms $\varnothing$ study because the $25(\mathrm{OH}) \mathrm{D}$ assay used resulted in smokers having $15-20 \%$ higher $25(\mathrm{OH}) \mathrm{D}$ concentrations than non-smokers which was not reproducible with other assays. ${ }^{9}$ In addition, study participants with missing $25(\mathrm{OH}) \mathrm{D}$ measurement, missing values for covariates used in the main model, or participants lost to follow-up due to unknown reasons were excluded. The derivation of the final number of included study participants is shown for each cohort in table $1 \Downarrow$.

\section{Mortality ascertainment}

All cohorts ascertained deaths by region, state, or country wide registries with a coverage of $\geq 98.5 \%$ and obtained information about the underlying cause of death for at least $97.6 \%$ of the deceased. The mean follow-up time ranged from 4.2 to 15.9 years (table $1 \Downarrow$ ). All deaths coded with ICD-10 codes I00-I99 were considered cardiovascular deaths, and cancer deaths were defined by the ICD-10 codes C00-C97.

\section{Measurement of 25(OH)D}

Measurement of 25(OH)D was conducted in the full cohorts of ESTHER, Troms $\varnothing$, and NHANES III, whereas in SENECA and MONICA/KORA random subsamples were measured, and in the three HAPIEE cohorts $25(\mathrm{OH}) \mathrm{D}$ was measured in a nested case-control design (including study participants who died from any cause as cases). Details of the sampling procedures, the design of the nested case-control study, and the manufacturers of the $25(\mathrm{OH}) \mathrm{D}$ assays are given in table $1 \Downarrow$, and further details have been described previously. ${ }^{2} 89111314$

\section{Covariate assessment}

Sociodemographic, lifestyle, anthropometric, and disease history data were assessed by self administered questionnaires or in interviews. In addition to self reported information, some studies measured weight and height and validated the history of common chronic diseases by consulting medical records or registries (such as cancer registries) (supplementary table 1). If measured anthropometric data or validated diagnoses were available, these were used in the analysis, and self reported 
information was used only to fill missing information. Prevalent cardiovascular disease was defined as a history of myocardial infarction or stroke.

\section{Statistical analyses}

This meta-analysis of individual participant data followed a two step approach by analysing the cohorts individually first and conducting meta-analyses of the obtained effect estimates thereafter.

Differences in 25(OH)D concentrations according to baseline characteristics were assessed with the Wilcoxon rank-sum test. The longitudinal analyses with mortality outcomes were conducted using $25(\mathrm{OH}) \mathrm{D}$ quintiles because there is still no consensus about cut off values for $25(\mathrm{OH}) \mathrm{D}$ risk categories ${ }^{8} 15$ and the applied 25(OH)D assays in the cohorts were not commonly standardised. The cut off values for $25(\mathrm{OH}) \mathrm{D}$ quintiles were allowed to vary by cohort and by analysed subgroup to ensure that there was always $20 \%$ of the analysed study population in each quintile (see supplementary table 2 for applied cut off values).

Cox proportional hazards or logistic regression models (the latter for case-control studies nested in the HAPIEE cohorts) were used to estimate hazard ratios or odds ratios, respectively, with $95 \%$ confidence intervals for comparison of increasing $25(\mathrm{OH}) \mathrm{D}$ quintiles compared with the highest quintile. When the risk is low, logistic and Cox regression usually produce similar results and the odds ratio can be regarded as an approximation of the more accurate hazard ratio that also takes time to the event into account. We use the term "risk ratios" for both the effect estimates. Analyses for cardiovascular and cancer mortality were stratified by presence or absence of a history of the disease. For sensitivity analyses of all-cause mortality, data were restricted to subjects without a history of cardiovascular disease or cancer, respectively. For analyses on cause-specific mortality, competing risks analysis was employed to correct for the competing risk of death by other causes. Weights for subjects who died of competing causes of death were determined according to an extension of the Fine and Gray method. ${ }^{16}$

For all outcomes, three models were applied with adjustment for an increasing number of established risk factors for all-cause mortality and determinants of serum $25(\mathrm{OH}) \mathrm{D}$ concentrations. In model 1, adjustment was made for age, sex, and season of blood draw. Model 2 was the fully adjusted model with additional adjustment for education, body mass index, smoking, and physical activity. Model 3 additionally included diseases that could potentially be intermediates in the association of $25(\mathrm{OH}) \mathrm{D}$ and mortality (that is, a history of diabetes, hypertension, cardiovascular disease, and cancer). Model 2 results were considered the main results. Age was modelled linearly and the other variables categorically with dummy variables using the categories shown in table $2 \Downarrow$. In addition, the following adjustments for cohort-specific characteristics were made in all three models: survey for MONICA/KORA, latitude of study centre for SENECA, and region (west, mid-west, north-east, south) as well as ethnicity (non-Hispanic white, non-Hispanic black, Mexican-American, other) for the NHANES III. Proportions of non-white study participants in the European studies were negligible.

For all meta-analyses, Mantel-Haenszel weighting and random effects models were used, ${ }^{17}$ taking the sample size of the cohorts and the possibility of statistical heterogeneity among the studies into account. The latter was examined with Cochrane's Q test and the $\mathrm{I}^{2}$ statistic. In sensitivity analyses, the nested case-control studies and, separately, death in the first three years of follow up were excluded from the meta-analyses, but this did not change the overall findings and these results are therefore not shown. Dose-response relationships were assessed by estimation of a trend underlying the summary effect estimates of the $25(\mathrm{OH}) \mathrm{D}$ quintiles applying the best fitting equation of the form $\mathrm{y}=\mathrm{m} \mathrm{x}^{\mathrm{b}}\left(\mathrm{y}\right.$, effect estimate; $\mathrm{m}$, constant $\mathrm{t}_{1}, \mathrm{x}=$ number of quintile (that is, 1, 2, 3, 4, or 5), $\mathrm{b}=$ constant $_{2}$ ).

Subgroups to be analysed were chosen a priori with the aim to stratify for the important non-modifiable risk factors for vitamin D deficiency: sex, age, and season of blood draw. ${ }^{8} 1819$

Cohort-specific subgroup analysis results were pooled in meta-analyses, and in a sensitivity analysis the pooling of results was restricted to those cohorts that could contribute data to all subgroup analyses (ESTHER, Troms $\emptyset$ and NHANES III). In a further sensitivity analysis, analyses were stratified by smoking status (current; yes or no) to examine whether excluding current smokers from the Troms $\emptyset$ study could have affected the results of the overall meta-analysis.

All statistical tests were two sided using an $\alpha$ level of 0.05 . The meta-analyses were conducted with the statistical software Comprehensive Meta-Analysis 2.0 (Biostat, Englewood NJ, USA), the dose-response trend was assessed with Microsoft Excel 2010 (Redmond, Washington, USA), and all other analyses were conducted with SAS, version 9.2 (Cary, North Carolina, USA). The competing risks analysis was carried out with a SAS macro provided by G Heinze, Medical University of Vienna, Austria. ${ }^{20}$

\section{Results}

The baseline characteristics of the analytical samples from participating cohorts and the nested case-control studies are shown in supplementary tables 3 and 4, respectively. All cohorts included men and women and all age groups (50-79 years), with exception of the SENECA study, which only recruited in the age range $70-79$ years. The median $25(\mathrm{OH}) \mathrm{D}$ concentrations by cohort varied between 24 and $62 \mathrm{nmol} / \mathrm{L}$. Lower values in the Troms $\varnothing$, MONICA/KORA, SENECA, and HAPIEE cohort studies can in part be explained by there being few or no serum samples being collected in summer or autumn. Interestingly, the medians of $25(\mathrm{OH}) \mathrm{D}$ concentrations in the nested case-control studies were consistently lower among cases than controls (supplementary table 4).

Table $2 \Downarrow$ shows $25(\mathrm{OH}) \mathrm{D}$ concentrations by baseline characteristics of the study participants (HAPIEE cohorts are again shown separately for cases and controls). There was no clear trend in $25(\mathrm{OH}) \mathrm{D}$ by age, but the median $25(\mathrm{OH}) \mathrm{D}$ concentrations were consistently lower among women than men. As expected, there was a clear pattern of $25(\mathrm{OH}) \mathrm{D}$ concentrations measured in winter or spring being substantially lower than those measured in summer or autumn. In addition, the median $25(\mathrm{OH}) \mathrm{D}$ concentrations were, with few exceptions among the cases and controls of the HAPIEE cohorts, increasing with categories of education, lowest in obese individuals, lowest in current smokers, and higher among subjects who undertook vigorous physical activity. There were no systematic differences in $25(\mathrm{OH}) \mathrm{D}$ concentrations between subjects with and without history of chronic diseases (diabetes, hypertension, cardiovascular disease, or cancer).

The median follow-up time in individual cohorts varied between 4.2 and 15.8 years, during which 6695 study participants died, including 2624 deaths from cardiovascular diseases and 2227 deaths from cancer (table $1 \Downarrow$ ). Compared with models adjusted for age, sex, and season (model 1), the risk ratios by $25(\mathrm{OH}) \mathrm{D}$ quintile (using the top quintile as reference) were attenuated for 
all outcomes by additional adjustment for conventional risk factors for premature mortality (model 2; supplementary tables 5-7). Further addition of common chronic diseases to the model (model 3) did not lead to further material attenuations of the risk ratios.

The forest plots of the meta-analyses of main results (model 2), comparing the bottom and the top $25(\mathrm{OH}) \mathrm{D}$ quintile are shown for all-cause mortality in fig $1 \Downarrow$ and for cardiovascular and cancer mortality in fig $2 \Downarrow$. A low degree of heterogeneity of effects in the individual cohort studies can be seen from the forest plots. The horizontal bars (the confidence intervals) overlap, and the boxes (the effect estimates) are mostly close together. The pooled effect estimate in the meta-analysis for all-cause mortality revealed a 1.6-fold higher mortality in the bottom quintile compared with the top quintile (risk ratio 1.57 (95\% confidence interval 1.36 to 1.81 ), fig $1 \Downarrow$ ). Furthermore, the association with cardiovascular mortality in subjects without a history of cardiovascular disease (risk ratio 1.41 (1.18 to 1.68)) and in subjects with a history of cardiovascular disease (risk ratio 1.65 (1.22 to 2.22)) and the association with cancer mortality in subjects with a history of cancer (1.70 (1.00 to 2.88)) were of similar strength and all statistically significant

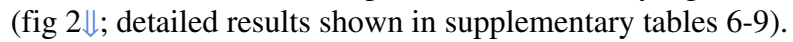
The only exception was cancer mortality in subjects without a history of cancer, for whom there was no association (risk ratio 1.03 (0.89 to 1.20$)$ ).

The dose-response trends across all 25(OH)D quintiles show curvilinear inverse associations for all-cause mortality and cardiovascular mortality, and for cancer mortality in subjects with a history of cancer (fig $3 \Downarrow$; detailed results shown in supplementary tables 5-9). For all-cause mortality, the risk ratio for bottom versus top $25(\mathrm{OH}) \mathrm{D}$ quintile was almost unchanged if subjects with a history of cardiovascular disease or of cancer were excluded (supplementary table 10-11).

In analyses stratified for sex, age, and season, the association of the bottom quintile of $25(\mathrm{OH}) \mathrm{D}$ concentration with the outcomes did not differ substantially in the subgroups (pooled results are shown in fig $4 \Downarrow$, detailed results are shown in supplementary tables 12-20). Restricting the analyses to cohorts that can contribute to all subgroups produced similar results (not shown), as did stratification by smoking status or exclusion of events in the first three years of follow-up (not shown).

Heterogeneity statistics for the meta-analyses usually indicated a low, statistically non-significant level of heterogeneity. When statistically significant, heterogeneity could be attenuated to non-significant levels by removal of one outlier study (supplementary tables 5-20). In the numerous meta-analyses, six out of the eight studies were identified as the outlier between one and three times, which shows that being the outlier was rather randomly distributed among the studies and did not indicate incomparability of the study's results.

\section{Discussion}

\section{Principal findings}

In this meta-analysis of eight prospective cohort studies from Europe and the United States, the lowest quintile of serum $25(\mathrm{OH}) \mathrm{D}$ concentration was associated with increased all-cause and cardiovascular mortality, with a curvilinear association between $25(\mathrm{OH}) \mathrm{D}$ concentration and these outcomes. An association with cancer mortality was only observed if subjects had a history of cancer. Results were consistent across study populations, sexes, age groups, and seasons of blood draw.

\section{Comparison with other studies}

This is the first meta-analysis of individual participant data on the relationship of 25(OH)D and mortality. Previous meta-analyses of published study results faced problems with hardly comparable vitamin D categories (including tertiles, quartiles, quintiles, or clinically defined categories).

Nevertheless, the pooled effect estimates from this meta-analysis for all-cause mortality (risk ratio 1.57 (95\% confidence interval 1.36 to 1.81$)$ ) and cardiovascular mortality (1.41 (1.18 to 1.68$)$ in subjects without cardiovascular disease at baseline) comparing the lowest and highest quintile of $25(\mathrm{OH}) \mathrm{D}$ concentration agreed with the meta-analyses of Zittermann et $\mathrm{al}^{21}$ for all-cause mortality (risk ratio 1.41 (1.04 to 1.90)) and of Wang et al ${ }^{22}$ for cardiovascular mortality (1.42 (1.19 to 1.71$)$ ). The most recent meta-analysis, by Chowdhury et $\mathrm{al},{ }^{23}$ that recalculated published effect estimates to derive comparisons of the bottom versus the top tertile of vitamin D levels came to similar effect estimates for all-cause mortality (relative risk 1.35 (1.22 to 1.49)) and cardiovascular mortality (1.35 (1.13 to 1.61$)$ ). None of the studies included in the reviews was conducted in eastern European populations, which differ from western European populations with respect to lifestyle (such as alcohol consumption and nutrition) and socioeconomic characteristics. ${ }^{24}$ Our meta-analysis shows that the associations of low 25(OH)D concentrations with all-cause and cardiovascular mortality outcomes are as strong in eastern Europe as in western Europe, northern Europe, or the US.

With respect to cancer mortality, the recent meta-analyses of Chowdhury et $\mathrm{al}^{23}$ and Yin et $\mathrm{al}^{25}$ showed weak, albeit statistically significant, elevated pooled risk ratios (1.14 (1.01 to 1.29 ) and 1.20 (1.02 to 1.43 ), respectively, after change of reference category to highest $25(\mathrm{OH}) \mathrm{D}$ category in the meta-analysis of Yin et al). Our meta-analysis revealed a clear difference in the association of $25(\mathrm{OH}) \mathrm{D}$ and cancer mortality between subjects with a history of cancer (risk ratio $1.70(1.00$ to 2.88$)$ ) and those without (1.03 (0.89 to 1.20$)$ ). This difference might explain why the pooled effect estimates of the previous meta-analyses were weak and why a large degree of heterogeneity was seen among the included studies. Moreover, it speaks for an important role of vitamin D in cancer prognosis (as recently shown by others for colorectal and breast cancer prognosis ${ }^{26}$ ). However, we cannot exclude reverse causality, that is, that the cancer might have led to low $25(\mathrm{OH}) \mathrm{D}$ levels. Furthermore, our study with the endpoint cancer mortality cannot make assumptions about a potential role of vitamin D in early phases of the carcinogenic process. A recent systematic umbrella review of meta-analyses of observational studies assessing the association of $25(\mathrm{OH}) \mathrm{D}$ levels with site-specific cancer incidences concluded that there is evidence for an association of 25(OH)D levels with colorectal cancer whereas there is inconclusive or no evidence for an association of $25(\mathrm{OH}) \mathrm{D}$ with other cancer sites. ${ }^{27}$

The median 25(OH)D concentrations varied strongly between northern, central and eastern Europe and the US in the same seasons of blood collection. However, it is uncertain how much of these differences are related to different ultraviolet B exposure, vitamin D consumption in the diet, and vitamin D fortification habits in the countries or are just artefacts of the different $25(\mathrm{OH}) \mathrm{D}$ assays employed. The distributions of various covariates were similar across the studies in this meta-analysis, but differences in the season of sample collection could have led to some of the observed differences. Importantly, the $25(\mathrm{OH}) \mathrm{D}$ assays used in the eight cohort studies were not standardised to a common standard, and large differences in concentrations may simply be due to different assay standards 
and materials. ${ }^{28}{ }^{29}$ However, a previous analysis of the SENECA study that used a common $25(\mathrm{OH}) \mathrm{D}$ assay for analysis in 12 European countries was in agreement with our finding that population means of $25(\mathrm{OH}) \mathrm{D}$ concentrations are higher in northern than in southern Europe (differences of $\geq 20 \mathrm{nmol} / \mathrm{L}$ were reported). ${ }^{2}$ The authors of the SENECA study mainly suspected country differences in vitamin $\mathrm{D}$ fortification of foods, such as margarine, as possible causes of the large regional differences. ${ }^{30}$ This could also explain the higher 25(OH)D levels in the US, where fortification of milk is the rule whereas it is the exception in Europe. ${ }^{31}$

In addition, this analysis in eight population based studies confirmed the observation of previous studies that $25(\mathrm{OH}) \mathrm{D}$ concentrations vary strongly by age, sex, season, education, obesity, physical activity, and smoking. ${ }^{818} 19$ Nevertheless, in our meta-analyses of mortality endpoints, the results were comparable despite cut-off values set at the quintiles varying by cohort (and therefore country), or by other factors such as age, sex, and season. Overall, this finding may support the view that low 25(OH)D concentrations might be a marker for a poor health status rather than a cause of premature mortality. The direction from a poor health state to vitamin D deficiency seems plausible because subjects with poor health typically spend less time outdoors because of reduced capacity for physical activity, limiting their production of provitamin $\mathrm{D}_{3}$ in the skin under solar ultraviolet B radiation. ${ }^{32}$

\section{Implications for vitamin D supplementation recommendations}

The question of causality could be best answered by randomised controlled trials. Two recent systematic reviews of such trials confirmed that vitamin D supply has an effect on mortality. ${ }^{23} 33$ However, the effects were weaker than suggested by observational studies, and vitamin D supplementation seemed to be effective only for the administration of vitamin $\mathrm{D}_{3}$ in subjects with low $25(\mathrm{OH}) \mathrm{D}$ levels at baseline. ${ }^{23}{ }^{33}$ Mortality was only a secondary outcome in most of the trials, initially designed to study the effects of vitamin D and calcium supplementation on osteoporotic outcomes. New trials with a focus on non-skeletal outcomes are needed. Four large trials have started in 2012 and are described elsewhere. ${ }^{34}$ Among these, the VIDAL study, which is currently undertaking a feasibility study, will be particularly informative with respect to mortality outcomes because it will be specifically designed to assess these endpoints in older adults (65-84 year old citizens of Great Britain). First results of this trial are expected between 2017 and 2020. Until then, it seems reasonable to follow the US Institute of Medicine recommendations that evidence is not yet sufficient to recommend vitamin $\mathrm{D}_{3}$ supplementation for subjects with vitamin D insufficiency (defined as 30-50 nmol/L 25(OH)D) but that subjects with vitamin $\mathrm{D}$ deficiency $(<30 \mathrm{nmol} / \mathrm{L}$ $25(\mathrm{OH}) \mathrm{D}$ ) could profit from vitamin $\mathrm{D}_{3}$ supplementation by maintaining bone health and reduction of fracture risk. ${ }^{35}$

However, there is no consensus on the ideal cut-off values for vitamin D deficiency, because they are currently based on the prevention of osteoporotic outcomes, and other outcomes might also be relevant. ${ }^{8}{ }^{15}$ In our view, all-cause mortality is an outcome with particularly high public health relevance and should therefore be given high priority. A recent analysis of the ESTHER cohort showed that the Institute of Medicine cut-offs for vitamin D deficiency and insufficiency are not only appropriate for osteoporotic outcomes but also for mortality prediction. ${ }^{8}$ The former ESTHER analysis had been adjusted for the main determinants of $25(\mathrm{OH}) \mathrm{D}$ levels and therefore corrected for variations in $25(\mathrm{OH}) \mathrm{D}$ levels according to season and sex. In this analysis, widely varying cut-off points specific for country, sex, and season produced similar results, which raises the question whether country, sex, and season might be considered for defining vitamin D deficiency. Future population based cohort studies with adequately standardised $25(\mathrm{OH}) \mathrm{D}$ measurements are essential to obtain sex- and season-specific cut-points for vitamin D deficiency. Caution should be used in generalising existing cut-offs to other regions with different latitudes.

\section{Limitations and strengths}

This meta-analysis of individual participant data has several strengths: the variety of cohorts from all over Europe and the US, the overall large size enabling subgroup analyses, almost complete registry-based follow-ups, and the common statistical analysis strategy. We did not use repeated $25(\mathrm{OH}) \mathrm{D}$ measurements during follow-up because this would not have had a strong influence on the results. Previous analyses of the Troms $\varnothing$ and ESTHER study showed that $25(\mathrm{OH}) \mathrm{D}$ concentrations are fairly stable even up to 14 years. ${ }^{86}$ The main limitation of this meta-analysis of prospective cohort studies is its observational nature. Despite adjustment for known potential confounders, we cannot rule out the possibility that the observed associations are confounded by other unmeasured factors, such as impairments of the immune system. ${ }^{32}$ In addition, residual confounding by variables that could have been measured with a higher degree of detail (such as physical activity) is possible but not a likely explanation for the observed strong associations between $25(\mathrm{OH}) \mathrm{D}$ concentrations and mortality outcomes.

\section{Conclusion}

In this meta-analysis of eight prospective cohort studies, the lowest $25(\mathrm{OH}) \mathrm{D}$ quintile was associated with increased all-cause mortality, cardiovascular mortality, and cancer mortality (in subjects with a history of cancer). The inverse association across quintiles was curvilinear, and the effects were remarkably consistent across countries, sexes, seasons of blood draw, and age groups despite $25(\mathrm{OH}) \mathrm{D}$ cut-off values varying according to these characteristics. To identify cut-off values for vitamin $\mathrm{D}$ deficiency, $25(\mathrm{OH}) \mathrm{D}$ variation by geographic region, sex, and season might need to be taken into account.

\section{Collaborators of the CHANCES group: Bernd Holleczek (Saarland} Cancer Registry, Germany); Christa Meisinger (Institute of Epidemiology II, German Research Center for Environmental Health, Germany); Wolfgang Koenig (Department of Internal Medicine II-Cardiology, University of Ulm Medical Center, Germany); Nicole Jankovic (Division of Human Nutrition, Wageningen University, Netherlands); Kari Kuulasmaa (National Institute for Health and Welfare, Helsinki, Finland). Contributors: All authors fulfil the criteria of authorship. Contributors participated in collection of data, analysis of data, coordination of the consortium, or obtaining of funding. Ben Schöttker is the guarantor of this work.

Funding: This analysis was part of the CHANCES project funded in the FP7 framework programme of DG-RESEARCH in the European Commission (Grant No 242244). The CHANCES project is coordinated by the Hellenic Health Foundation, Greece. Further funding sources of participating cohorts: The ESTHER study was funded by the Baden-Württemberg state Ministry of Science, Research and Arts (Stuttgart, Germany), the Federal Ministry of Education and Research (Berlin, Germany) and the Federal Ministry of Family Affairs, Senior Citizens, Women and Youth (Berlin, Germany). Measurements of $25(\mathrm{OH}) \mathrm{D}$ in men were conducted in the context of the German Cancer Aid project number 108250 and 108426. The Tromsø Study was 


\section{What is already known on this subject}

Mean serum 25-hydroxyvitamin D (25(OH)D) concentrations vary by country, sex, age, and season of blood draw

Vitamin $\mathrm{D}$ deficiency has been linked to all-cause and cardiovascular mortality, whereas results on cancer mortality have been inconsistent

\section{What this study adds}

In this large consortium of eight cohort studies from Europe and the United States, the bottom 25(OH)D quintile was associated with increased all-cause and cardiovascular mortality and with cancer mortality in subjects with a history of cancer but not in subjects without a history of cancer. These relationships were compellingly consistent across countries, sexes, age groups, and seasons of blood draw, although cut-off values for the $25(\mathrm{OH}) \mathrm{D}$ quintiles varied among the analyses

In clinical practice, cut-off values for vitamin D deficiency might need to be made region-, sex-, and season-specific to identify those in the population with the relatively lowest $25(\mathrm{OH}) \mathrm{D}$ concentrations

Vitamin D may play an important role in cancer prognosis

performed by the University of Tromsø in cooperation with the National Health Screening Service. The study was funded by the Norwegian Research Council. The MONICA/KORA Augsburg cohort study was financed by the Helmholtz Zentrum München, German Research Center for Environmental Health which is funded by the German Federal Ministry of Education and Research and by the State of Bavaria and supported by grants from the German Federal Ministry of Education and Research. Additional funds for the present study were provided by the German Research Foundation (TH-784/2-1 and TH-784/2-2), the Federal Ministry of Health, the University of UIm, the German Diabetes Center and the Ministry of Innovation, Science, Research, and Technology of the state North Rhine Westphalia. For this analysis, data of the MONICA/KORA Augsburg study were provided by the MORGAM Data Centre, at THL in Helsinki, Finland. CHANCES funding was used for data coding and transfer. The SENECA study was funded as a Concerted Action within the EURONUT programme of the EU. The HAPIEE study was funded by the Welcome Trust (064947 and 081081), the US National Institute on Ageing (R01 AG23522-01), and a grant from Mac Arthur Foundation. The study's funders played no role in study design; in the collection, analysis, and interpretation of data; in the writing of the report; and in the decision to submit the article for publication. The researchers were independent from the funders.

Competing interests: All authors have completed the ICMJE uniform disclosure form at www.icmje.org/coi_disclosure.pdf (available on request from the corresponding author) and declare: no support from any organisation for the submitted work; no financial relationships with any organisations that might have an interest in the submitted work in the previous three years; no other relationships or activities that could appear to have influenced the submitted work.

Ethical approval: The included studies have been approved by local ethics committees: ESTHER: Medical Faculty of the University of Heidelberg and the Medical Association of Saarland; HAPIEE: University College London (Great Britain), National Institute of Public Health (Prague, Czech Republic), Jagiellonian University (Krakow, Poland) and Lithuanian University of Health Sciences (Kaunas, Lithuania); Tromsø Study: The Regional Committee for Medical and Health Research Ethics and the Data Inspectorate of Norway; MONICA/KORA: Local authorities and the Bavarian State Chamber of Physicians. SENECA: Local ethics approval by the SENECA participating centres (e.g. Wageningen University ethics committee).

Informed consent has been obtained from all participants included in the analysed studies and the studies are being conducted in accordance with the declaration of Helsinki.

Transparency: The lead author (the manuscript's guarantor) affirms that the manuscript is an honest, accurate, and transparent account of the study being reported; that no important aspects of the study have been omitted; and that any discrepancies from the study as planned have been explained.

Data sharing: No additional data available
2 van der Wielen RP, Löwik MR, van den Berg H, de Groot LC, Haller J, Moreiras O, et al. Serum vitamin D concentrations among elderly people in Europe. Lancet 1995;346:207-10. 3 Kestenbaum B, Katz R, de Boer I, Hoofnagle A, Sarnak MJ, Shlipak MG, et al. Vitamin D, parathyroid hormone, and cardiovascular events among older adults. J Am Coll Cardiol 2011;58:1433-41.

4 Chang EM, Kim YS, Won HJ, Yoon TK, Lee WS. Association between sex steroids, ovarian reserve, and vitamin D levels in healthy non-obese women. J Clin Endocrinol Metab 2014:jc20133873.

5 Mosekilde L. Vitamin D and the elderly. Clin Endocrinol (Oxf) 2005;62:265-81.

6 von Elm E, Altman DG, Egger M, Pocock SJ, Gøtzsche PC, Vandenbroucke JP; STROBE Initiative. Strengthening the Reporting of Observational Studies in Epidemiology (STROBE) statement: guidelines for reporting observational studies. BMJ 2007;335:806-8.

7 Stroup DF, Berlin JA, Morton SC, Olkin I, Williamson GD, Rennie D, et al. Meta-analysis of observational studies in epidemiology: a proposal for reporting. Meta-analysis Of Observational Studies in Epidemiology (MOOSE) group. JAMA 2000;283:2008-12.

8 Schöttker B, Haug U, Schomburg L, Köhrle J, Perna L, Müller H, et al. Strong associations of 25-hydroxyvitamin D concentrations with all-cause, cardiovascular, cancer, and respiratory disease mortality in a large cohort study. Am J Clin Nutr 2013;97:782-93.

9 Hutchinson MS, Grimnes G, Joakimsen RM, Figenschau Y, Jorde R. Low serum 25-hydroxyvitamin $\mathrm{D}$ levels are associated with increased all-cause mortality risk in a general population: the Tromsø study. Eur J Endocrinol 2010;162:935-42.

10 Thorand B, Kolb H, Baumert J, Koenig W, Chambless L, Meisinger C, et al. Elevated levels of interleukin-18 predict the development of type 2 diabetes: results from the MONICA/KORA Augsburg Study, 1984-2002. Diabetes 2005;54:2932-8.

11 Melamed ML, Michos ED, Post W, Astor B. 25-hydroxyvitamin D levels and the risk of mortality in the general population. Arch Intern Med 2008;168:1629-37.

12 Peasey A, Bobak M, Kubinova R, Malyutina S, Pajak A, Tamosiunas A, et al. Determinants of cardiovascular disease and other non-communicable diseases in Central and Eastern Europe: rationale and design of the HAPIEE study. BMC Public Health 2006;6:255.

13 Thorand B, Zierer A, Huth C, Linseisen J, Meisinger C, Roden M, et al. Effect of serum 25 -hydroxyvitamin $D$ on risk for type 2 diabetes may be partially mediated by subclinical inflammation: results from the MONICA/KORA Augsburg study. Diabetes Care 2011;34:2320-2.

14 Karakas M, Thorand B, Zierer A, Huth C, Meisinger C, Roden M, et al. Low levels of serum 25-hydroxyvitamin $D$ are associated with increased risk of myocardial infarction, especially in women: results from the MONICA/KORA Augsburg case-cohort study. J Clin Endocrinol Metab 2013;98:272-80.

15 Brouwer-Brolsma EM, Bischoff-Ferrari HA, Bouillon R, Feskens EJ, Gallagher CJ, Hypponen E, et al. Vitamin D: do we get enough? A discussion between vitamin D experts in order to make a step towards the harmonisation of dietary reference intakes for vitamin D across Europe. Osteoporos Int 2013;24:1567-77.

16 Geskus RB. Cause-specific cumulative incidence estimation and the fine and gray model under both left truncation and right censoring. Biometrics 2011;67:39-49.

17 DerSimonian R, Laird N. Meta-analysis in clinical trials. Control Clin Trials 1986;7:177-88

18 De Boer IH, Levin G, Robinson-Cohen C, Biggs ML, Hoofnagle AN, Siscovick DS, et al. Serum 25-hydroxyvitamin $\mathrm{D}$ concentration and risk for major clinical disease events in a community-based population of older adults: a cohort study. Ann Intern Med 2012;156:627-34.

19 Durup D, Jørgensen HL, Christensen J, Schwarz P, Heegaard AM, Lind B. A reverse $\mathrm{J}$-shaped association of all-cause mortality with serum 25 -hydroxyvitamin $D$ in general practice: the CopD study. J Clin Endocrinol Metab 2012;97:2644-52.

20 Kohl M, Heinze G. PSHREG: A SAS macro for proportional and nonproportional subdistribution hazards regression with competing risk data. 2012. http://cemsiis. meduniwien.ac.at $/ \mathrm{kb}$

21 Zittermann A, lodice S, Pilz S, Grant WB, Bagnardi V, Gandini S. Vitamin D deficiency and mortality risk in the general population: a meta-analysis of prospective cohort studies. Am J Clin Nutr 2012;95:91-100.

22 Wang L, Song Y, Manson JE, Pilz S, März W, Michaëlsson K, et al. Circulating 25-hydroxy-vitamin $\mathrm{D}$ and risk of cardiovascular disease: a meta-analysis of prospective studies. Circ Cardiovasc Qual Outcomes 2012;5:819-29.

23 Chowdhury R, Kunutsor S, Vitezova A, Oliver-Williams C, Chowdhury S, Kiefte-de-Jong $\mathrm{JC}$, et al. Vitamin $\mathrm{D}$ and risk of cause specific death: systematic review and meta-analysis of observational cohort and randomised intervention studies. BMJ 2014;348:g1903.

24 Boylan S, Lallukka T, Lahelma E, Pikhart H, Malyutina S, Pajak A, et al. Socio-economic circumstances and food habits in Eastern, Central and Western European populations. Public Health Nutr 2011;14:678-87.

25 Yin L, Ordóñez-Mena JM, Chen T, Schöttker B, Arndt V, Brenner H. Circulating 25-hydroxyvitamin $D$ serum concentration and total cancer incidence and mortality: a systematic review and meta-analysis. Prev Med 2013;57:753-64.

26 Maalmi H, Ordóñez-Mena JM, Schöttker B, Brenner H. Serum 25-hydroxyvitamin D levels and survival in colorectal and breast cancer patients: systematic review and meta-analysis of prospective cohort studies. Eur J Cancer 2014;50:1510-21.

27 Theodoratou E, Tzoulaki I, Zgaga L, loannidis JP. Vitamin D and multiple health outcomes: umbrella review of systematic reviews and meta-analyses of observational studies and randomised trials. BMJ 2014;348:g2035. 
28 Schöttker B, Jansen EH, Haug U, Schomburg L, Köhrle J, Brenner H. Standardization of misleading immunoassay based 25-hydroxyvitamin $\mathrm{D}$ levels with liquid chromatography tandem-mass spectrometry in a large cohort study. PLoS One 2012;7:e48774.

29 Carter GD, Carter R, Jones J, Berry J. How accurate are assays for 25-hydroxyvitamin $\mathrm{D}$ ? Data from the international vitamin D external quality assessment scheme. Clin Chem 2004;50:2195-7.

30 Chun RF. New perspectives on the vitamin D binding protein. Cell Biochem Funct 2012;30:445-56.

31 Holick MF. The vitamin D deficiency pandemic: a forgotton hormone important for health. Public Health Rev 2010;32:267-83.

32 Autier $\mathrm{P}$, Boniol M, Pizot C, Mullie P. Vitamin D status and ill health: a systematic review. Lancet Diabetes Endocrinol 2014;2:76-89.

33 Bjelakovic G, Gluud LL, Nikolova D, Whitfield K, Wetterslev J, Simonetti RG, et al. Vitamin D supplementation for prevention of mortality in adults. Cochrane Database Syst Rev 2014;1:CD007470.

34 Kupferschmidt K. Uncertain verdict as vitamin D goes on trial. Science 2012;337:1476-8.
35 Committee to Review Dietary Reference Intakes for Vitamin D and Calcium. Food and Nutrition Board, Institute of Medicine. Dietary reference intakes for calcium and vitamin D. National Academies Press, 2011

36 Jorde R, Sneve M, Hutchinson M, Emaus N, Figenschau Y, Grimnes G. Tracking of serum 25-hydroxyvitamin $\mathrm{D}$ levels during 14 years in a population-based study and during 12 months in an intervention study. Am J Epidemiol 2010;171:903-8.

\section{Accepted: 19 May 2014}

\section{Cite this as: BMJ 2014;348:g3656}

This is an Open Access article distributed in accordance with the Creative Commons Attribution Non Commercial (CC BY-NC 3.0) license, which permits others to distribute, remix, adapt, build upon this work non-commercially, and license their derivative works on different terms, provided the original work is properly cited and the use is non-commercial. See: http://creativecommons.org/licenses/by-nc/3.0/. 


\section{Tables}

Table 1| Description of cohort studies included in meta-analyses of the associations between serum 25-hydroxyvitamin D concentrations and mortality outcomes

\begin{tabular}{|c|c|c|c|c|c|c|c|c|c|c|c|c|c|}
\hline \multirow[b]{2}{*}{ Study name } & \multirow[b]{2}{*}{$\begin{array}{l}\text { Place and } \\
\text { years of } \\
\text { recruitment }\end{array}$} & \multirow[b]{2}{*}{$\begin{array}{l}\text { 25(OH)D } \\
\text { assay }^{*}\end{array}$} & \multirow[b]{2}{*}{ Sampling } & \multicolumn{4}{|c|}{ Study population aged $50-79$ years } & \multicolumn{6}{|c|}{ Mortality follow-up } \\
\hline & & & & Total & $\begin{array}{c}\text { With } \\
\text { measured } \\
\text { 25(OH)D }\end{array}$ & $\begin{array}{l}\text { Included in } \\
\text { analysis } \dagger\end{array}$ & $\begin{array}{c}\text { Age } \\
\text { range }\end{array}$ & Registry & $\begin{array}{c}\text { End of } \\
\text { follow-up }\end{array}$ & $\begin{array}{c}\text { Mean } \\
\text { (SD) } \\
\text { follow-up } \\
\text { (years) }\end{array}$ & $\begin{array}{c}\text { Total } \\
\text { deaths }\end{array}$ & $\begin{array}{c}\text { CVD } \\
\text { deaths }\end{array}$ & $\begin{array}{l}\text { Cancer } \\
\text { deaths }\end{array}$ \\
\hline ESTHER & $\begin{array}{l}\text { Federal state } \\
\text { Saarland, } \\
\text { south west } \\
\text { Germany, } \\
2000-02\end{array}$ & $\begin{array}{c}\text { Men: } \\
\text { IDS-iSYS; } \\
\text { women: } \\
\text { Diasorin. } \\
\text { Both } \\
\text { standardised } \\
\text { to LC-MS/MS }\end{array}$ & Total cohort & 9949 & 9563 & 9083 & $50-74$ & $\begin{array}{l}\text { State } \\
\text { wide }\end{array}$ & 2012 & $11.0(2.2)$ & 1338 & 420 & 531 \\
\hline Tromsø & $\begin{array}{c}\text { Town } \\
\text { Tromsø, } \\
\text { north Norway, } \\
1994-95 \\
\text { (Tromsø 4) }\end{array}$ & $\begin{array}{c}\text { Modular } \\
\text { E170 Roche }\end{array}$ & Total cohort & 10262 & 6571 & $\begin{array}{c}4406 \ddagger \\
\text { non-smokers }\end{array}$ & $50-79$ & $\begin{array}{l}\text { Country } \\
\text { wide }\end{array}$ & 2010 & $14.2(3.6)$ & 1141 & 498 & 413 \\
\hline MONICA/KORA & $\begin{array}{c}\text { Town } \\
\text { Augsburg and } \\
\text { district, south } \\
\text { Germany, } \\
\text { 1984-85, } \\
1989-90, \\
1994-95\end{array}$ & IDS-iSYS & $\begin{array}{l}\text { Random } \\
\text { subsample§ }\end{array}$ & 6316 & 962 & 939 & $50-74$ & $\begin{array}{l}\text { Region } \\
\text { wide }\end{array}$ & 2009 & $15.9(5.7)$ & 366 & 165 & 66 \\
\hline SENECA & $\begin{array}{c}19 \text { towns in } \\
12 \text { European } \\
\text { countries, } \\
1988-89\end{array}$ & $\begin{array}{c}\text { Competitive } \\
\text { protein } \\
\text { binding } \\
\text { assay }\end{array}$ & $\begin{array}{l}\text { Random } \\
\text { subsampleף }\end{array}$ & 2586 & 823 & $661^{* *}$ & $70-75$ & $\begin{array}{l}\text { Region } \\
\text { wide }\end{array}$ & 1998 & $8.3(2.9)$ & 270 & 94 & 51 \\
\hline $\begin{array}{l}\text { HAPIEE Czech } \\
\text { Republic }\end{array}$ & $\begin{array}{l}6 \text { towns in } \\
\text { Czech } \\
\text { Republic, } \\
2002-05\end{array}$ & $\begin{array}{l}\text { DIAsource } \\
\text { ELISA }\end{array}$ & $\begin{array}{c}\text { Nested } \\
\text { case-controlt† }\end{array}$ & 7099 & 2280 & 2029 & $50-73$ & $\begin{array}{l}\text { Country } \\
\text { wide }\end{array}$ & 2011 & $7.9(1.5)$ & 453 & 165 & 208 \\
\hline HAPIEE Poland & $\begin{array}{l}\text { Town } \\
\text { Krakow, } \\
\text { Poland, } \\
2002-05 \\
\end{array}$ & $\begin{array}{l}\text { DIAsource } \\
\text { ELISA }\end{array}$ & $\begin{array}{c}\text { Nested } \\
\text { case-controlt† }\end{array}$ & 8121 & 1879 & 1700 & $50-71$ & $\begin{array}{l}\text { Region } \\
\text { wide }\end{array}$ & 2011 & $7.0(1.2)$ & 411 & 133 & 194 \\
\hline $\begin{array}{l}\text { HAPIEE } \\
\text { Lithuania }\end{array}$ & $\begin{array}{c}\text { Town } \\
\text { Kaunas, } \\
\text { Lithuania, } \\
\text { 2006-08 }\end{array}$ & $\begin{array}{l}\text { DIAsource } \\
\text { ELISA }\end{array}$ & $\begin{array}{c}\text { Nested } \\
\text { case-controlt† }\end{array}$ & 6339 & 1691 & 1574 & $50-74$ & $\begin{array}{l}\text { Region } \\
\text { wide }\end{array}$ & 2011 & $4.2(1.2)$ & 368 & 146 & 152 \\
\hline NHANES III & $\begin{array}{c}\text { USA } \\
1988-94\end{array}$ & Diasorin RIA & Total cohort & 6822 & 5740 & 5626 & $50-79$ & $\begin{array}{l}\text { Country } \\
\text { wide }\end{array}$ & 2006 & $12.3(4.5)$ & 2348 & 1003 & 612 \\
\hline Total & - & - & - & 57376 & 29509 & 26018 & $50-79$ & - & - & - & 6695 & 2624 & 2227 \\
\hline
\end{tabular}

25(OH)D=25-hydroxyvitamin D; CVD=cardiovascular disease; ESTHER=Epidemiologische Studie zu Chancen der Verhütung, Früherkennung und optimierten Therapie chronischer Erkrankungen in der älteren Bevölkerung [German]; HAPIEE=Health, Alcohol and Psychosocial factors In Eastern Europe; LC-MS/MS=liquid chromatography coupled with tandem mass spectrometry; MONICA/KORA=Monitoring of trends and determinants in cardiovascular disease-Cooperative Health Research in the Region of Augsburg; NHANES=National Health and Nutrition Examination Survey; SENECA=Survey in Europe on Nutrition and the Elderly: a Concerted Action. ${ }^{*}$ Manufacturers of 25(OH)D assays: IDS-iSYS (Immunodiagnostic Systems, Frankfurt Main, Germany); Diasorin-Liaison (Diasorin, Stillwater, USA); DIAsource ELISA (DIAsource ImmunoAssays, Louvain-La-Neuve, Belgium); Modular E170 Roche (Roche Diagnostics, Rotkreuz, Swizerland) and competitive protein-binding assay (not commercially available).

†Numbers are lower than numbers with measured $25(\mathrm{OH}) \mathrm{D}$ due to missing covariates.

‡2 012 smokers were excluded from the Tromsø study because of concerns regarding the validity of the Roche 25(OH)D assay in smokers.

$\S$ Randomly selected stratified survey, sex and 10 year age groups.

\25(OH)D concentrations were measured in random samples stratified by age and sex in those 16 of the 19 towns with blood collected during January and March 1989. ${ }^{* *}$ Further two towns with 73 participants with measured 25(OH)D were excluded from this analysis because these towns did not participate in the mortality follow-up, leaving the following 14 towns from 12 European countries for inclusion in this analysis. North Europe (Latitude $>50^{\circ}$ north): Elverum, Norway; Roskilde, Denmark; Culemborg, Netherlands; Hamme, Belgium; central Europe (Latitude 45-59॰ north): Haguenau, France; Monor, Hungary; Burgdorf, Switzerland; Bellinzona, Switzerland; 
Table 1 (continued)

\begin{tabular}{|c|c|c|c|c|c|c|c|c|c|c|c|c|}
\hline \multirow[b]{2}{*}{ Study name } & \multirow[b]{2}{*}{$\begin{array}{c}\text { Place and } \\
\text { years of } \\
\text { recruitment }\end{array}$} & \multirow[b]{2}{*}{$\begin{array}{l}\text { 25(OH)D } \\
\text { assay }^{*}\end{array}$} & \multirow[b]{2}{*}{ Sampling } & \multicolumn{4}{|c|}{ Study population aged $50-79$ years } & \multicolumn{5}{|c|}{ Mortality follow-up } \\
\hline & & & & Total & $\begin{array}{c}\text { With } \\
\text { measured } \\
\text { 25(OH)D }\end{array}$ & $\begin{array}{l}\text { Included in } \\
\text { analysis } \dagger\end{array}$ & $\begin{array}{c}\text { Age } \\
\text { range }\end{array}$ & $\begin{array}{c}\text { End of } \\
\text { Registry follow-up }\end{array}$ & $\begin{array}{c}\text { Mean } \\
\text { (SD) } \\
\text { follow-up } \\
\text { (years) }\end{array}$ & $\begin{array}{c}\text { Total } \\
\text { deaths }\end{array}$ & $\begin{array}{c}\text { CVD } \\
\text { deaths }\end{array}$ & $\begin{array}{l}\text { Cancer } \\
\text { deaths }\end{array}$ \\
\hline
\end{tabular}

Yverdon, Switzerland; Romans, France; south Europe (Latitude $<45^{\circ}$ north): Betanzos, Spain; Fara Sabina, Magliano Sabina, Poggio Mirteto, Italy; Vila Franca de Xira, Portugal; Anogia, Archanes, Greece.

††25(OH)D was measured in cases (any death or non-fatal cardiovascular disease (CVD) event during follow-up) and controls frequency matched by sex and 5 year age groups. For this analysis on mortality, subjects with non-fatal CVD during follow-up were excluded from the cases in a first step. In order to add a representative sample of subjects with non-fatal CVD events to the controls, in a second step, the observed proportion of non-fatal CVD events in each age and sex specific stratum in the total cohort was calculated. In a third step, these proportions were multiplied by the sample sizes in each stratum in the controls with measured $25(\mathrm{OH}) \mathrm{D}$. In a fourth step, the resulting numbers were randomly selected in each stratum from the group of subjects with non-fatal CVD during follow-up and added to the controls. 


\begin{tabular}{|c|c|c|c|c|c|c|c|c|c|c|c|}
\hline \multirow[b]{3}{*}{ Characteristic } & \multicolumn{11}{|c|}{ Median (interquartile range) concentration of $25(\mathrm{OH}) \mathrm{D}(\mathrm{nmol} / \mathrm{L})^{*}$} \\
\hline & \multirow[b]{2}{*}{ ESTHER } & \multirow[b]{2}{*}{ Tromsø } & \multirow[b]{2}{*}{ MONICA-KORA } & \multirow[b]{2}{*}{ SENECA† } & \multirow[b]{2}{*}{ NHANES $¥$} & \multicolumn{2}{|c|}{ HAPIEE Czech Rep } & \multicolumn{2}{|c|}{ HAPIEE Poland } & \multicolumn{2}{|c|}{ HAPIEE Lithuania } \\
\hline & & & & & & Controls & Cases & Controls & Cases & Controls & Cases \\
\hline \multicolumn{12}{|l|}{ Age (years): } \\
\hline $50-59$ & $\begin{array}{c}47 \\
(35-63)^{\star}\end{array}$ & $\begin{array}{c}56 \\
(46-67)^{\star}\end{array}$ & $40(29-54)$ & NA & $60(44-80)^{*}$ & $\begin{array}{c}26 \\
(18-39) \\
\end{array}$ & $\begin{array}{c}21 \\
(14-30) \\
\end{array}$ & $\begin{array}{c}38 \\
(29-48) \\
\end{array}$ & $\begin{array}{c}34 \\
(24-43) \\
\end{array}$ & $\begin{array}{c}46 \\
(37-58)\end{array}$ & $\begin{array}{c}40 \\
(30-56) \\
\end{array}$ \\
\hline $60-69$ & $\begin{array}{c}46 \\
(35-62)^{\star}\end{array}$ & $\begin{array}{c}53 \\
(42-64)^{*} \\
\end{array}$ & $42(31-56)$ & NA & $61(45-80)^{*}$ & $\begin{array}{c}31 \\
(21-43)\end{array}$ & $\begin{array}{c}24 \\
(16-36) \\
\end{array}$ & $\begin{array}{c}39 \\
(30-51) \\
\end{array}$ & $\begin{array}{c}36 \\
(26-49) \\
\end{array}$ & $\begin{array}{c}46 \\
(37-59)\end{array}$ & $\begin{array}{c}41 \\
(30-53) \\
\end{array}$ \\
\hline 70-79 & $\begin{array}{c}43 \\
(33-57)^{\star}\end{array}$ & $\begin{array}{c}51 \\
(41-63)^{\star} \\
\end{array}$ & $36(27-50)$ & $33(23-47)$ & $64(48-82)^{*}$ & $\begin{array}{c}29 \\
(20-45) \\
\end{array}$ & $\begin{array}{c}34 \\
(21-56) \\
\end{array}$ & $\begin{array}{c}41 \\
(34-49) \\
\end{array}$ & $\begin{array}{c}43 \\
(28-76) \\
\end{array}$ & $\begin{array}{c}46 \\
(37-59) \\
\end{array}$ & $\begin{array}{c}45 \\
(33-56) \\
\end{array}$ \\
\hline \multicolumn{12}{|l|}{ Sex: } \\
\hline Women & $\begin{array}{c}43 \\
(33-54)^{\star}\end{array}$ & $\begin{array}{c}52 \\
(42-64)^{*}\end{array}$ & $37(29-49)^{*}$ & $31(21-44)^{*}$ & $57(42-76)^{*}$ & $\begin{array}{c}26 \\
(18-38)^{*}\end{array}$ & $\begin{array}{c}20 \\
(14-29)^{*}\end{array}$ & $\begin{array}{c}37 \\
(28-47)^{\star}\end{array}$ & $\begin{array}{c}32 \\
(23-40)^{*}\end{array}$ & $\begin{array}{c}44 \\
(35-56)^{*}\end{array}$ & $\begin{array}{c}38 \\
(29-49)^{*}\end{array}$ \\
\hline Men & $\begin{array}{c}52 \\
(37-71)^{*} \\
\end{array}$ & $\begin{array}{c}56 \\
(46-66)^{\star} \\
\end{array}$ & $44(31-60)^{*}$ & $35(26-49)^{*}$ & $67(50-85)^{*}$ & $\begin{array}{c}31 \\
(21-44)^{*} \\
\end{array}$ & $\begin{array}{c}26 \\
(17-38)^{*} \\
\end{array}$ & $\begin{array}{c}40 \\
(31-51)^{\star}\end{array}$ & $\begin{array}{c}37 \\
(27-50)^{*}\end{array}$ & $\begin{array}{c}47 \\
(37-60)^{*}\end{array}$ & $\begin{array}{c}44 \\
(32-57)^{*}\end{array}$ \\
\hline \multicolumn{12}{|l|}{ Season§: } \\
\hline Winter & $\begin{array}{c}40 \\
(31-54)^{\star}\end{array}$ & $\begin{array}{c}51 \\
(41-63)^{*}\end{array}$ & $36(27-52)^{*}$ & $32(22-45)^{\star}$ & $58(43-77)^{\star}$ & $\begin{array}{c}28 \\
(19-40)^{*}\end{array}$ & $\begin{array}{c}24 \\
(16-35)^{*}\end{array}$ & $\begin{array}{c}38 \\
(29-49)\end{array}$ & $\begin{array}{c}35 \\
(25-47)\end{array}$ & $\begin{array}{c}41 \\
(35-51)^{*}\end{array}$ & $\begin{array}{c}40 \\
(30-55)\end{array}$ \\
\hline Spring & $\begin{array}{c}40 \\
(32-52)^{\star}\end{array}$ & $\begin{array}{c}57 \\
(46-68)^{\star}\end{array}$ & $37(27-49)^{*}$ & $37(27-53)^{*}$ & $58(43-76)^{*}$ & $\begin{array}{c}28 \\
(18-40)^{\star}\end{array}$ & $\begin{array}{c}21 \\
(14-30)^{*}\end{array}$ & $\begin{array}{c}39 \\
(30-50)\end{array}$ & $\begin{array}{c}35 \\
(26-47)\end{array}$ & $\begin{array}{c}44 \\
(35-56)^{*}\end{array}$ & $\begin{array}{c}38 \\
(29-50)\end{array}$ \\
\hline Summer & $\begin{array}{c}53 \\
(41-70)^{*} \\
\end{array}$ & $\begin{array}{c}64 \\
(53-75)^{\star} \\
\end{array}$ & $49(36-61)^{\star}$ & NA & $67(49-84)^{*}$ & NA & NA & NA & NA & $\begin{array}{c}48 \\
(40-58)^{*} \\
\end{array}$ & $\begin{array}{c}45 \\
(31-51) \\
\end{array}$ \\
\hline Autumn & $\begin{array}{c}50 \\
(37-67)^{\star} \\
\end{array}$ & $\begin{array}{c}51 \\
(42-63)^{*} \\
\end{array}$ & $48(38-65)^{*}$ & NA & $65(48-85)^{*}$ & $\begin{array}{c}35 \\
(24-45)^{*} \\
\end{array}$ & $\begin{array}{c}28 \\
(19-43)^{*}\end{array}$ & $\begin{array}{c}43 \\
(33-54) \\
\end{array}$ & $\begin{array}{c}35 \\
(23-49) \\
\end{array}$ & $\begin{array}{c}51 \\
(40-64)^{*} \\
\end{array}$ & $\begin{array}{c}45 \\
(34-58) \\
\end{array}$ \\
\hline \multicolumn{12}{|l|}{ Educationף: } \\
\hline Low & $\begin{array}{c}45 \\
(34-61)^{*}\end{array}$ & $\begin{array}{c}52 \\
(41-63)^{*}\end{array}$ & $35(27-46)^{*}$ & $32(23-47)^{*}$ & $60(45-79)^{\star}$ & $\begin{array}{c}25 \\
(16-38)^{*} \\
\end{array}$ & $\begin{array}{c}20 \\
(13-32)^{*}\end{array}$ & $\begin{array}{c}36 \\
(28-46)^{\star}\end{array}$ & $\begin{array}{c}32 \\
(25-43)\end{array}$ & $\begin{array}{c}46 \\
(38-56)\end{array}$ & $\begin{array}{c}45 \\
(34-55)\end{array}$ \\
\hline Medium & $\begin{array}{c}47 \\
(35-64)^{*} \\
\end{array}$ & $\begin{array}{c}55 \\
(45-67)^{*} \\
\end{array}$ & $42(31-57)^{\star}$ & $36(26-50)^{*}$ & $62(46-81)^{\star}$ & $\begin{array}{c}29 \\
(20-41)^{*} \\
\end{array}$ & $\begin{array}{c}24 \\
(16-35)^{*} \\
\end{array}$ & $\begin{array}{c}39 \\
(30-50)^{\star}\end{array}$ & $\begin{array}{c}37 \\
(25-48) \\
\end{array}$ & $\begin{array}{c}45 \\
(37-57) \\
\end{array}$ & $\begin{array}{c}39 \\
(29-50) \\
\end{array}$ \\
\hline High & $\begin{array}{c}49 \\
(35-67)^{\star}\end{array}$ & $\begin{array}{c}57 \\
(46-68)^{\star} \\
\end{array}$ & $46(33-64)^{\star}$ & $40(29-56)^{*}$ & $65(47-84)^{\star}$ & $\begin{array}{c}34 \\
(21-45)^{*} \\
\end{array}$ & $\begin{array}{c}29 \\
(21-38)^{*}\end{array}$ & $\begin{array}{c}39 \\
(30-53)^{*}\end{array}$ & $\begin{array}{c}35 \\
(26-46) \\
\end{array}$ & $\begin{array}{c}47 \\
(37-60) \\
\end{array}$ & $\begin{array}{c}44 \\
(31-56) \\
\end{array}$ \\
\hline \multicolumn{12}{|l|}{$\mathrm{BMI} \mathrm{I}^{\star *}$} \\
\hline $\begin{array}{c}\text { Normal or } \\
\text { underweight }\end{array}$ & $\begin{array}{c}47 \\
(35-63)^{\star}\end{array}$ & $\begin{array}{c}56 \\
(45-67)^{\star} \\
\end{array}$ & $41(30-57)$ & $32(22-51)^{*}$ & $65(47-86)^{*}$ & $\begin{array}{c}30 \\
(18-44)^{\star} \\
\end{array}$ & $\begin{array}{c}23 \\
(17-40) \\
\end{array}$ & $\begin{array}{c}39 \\
(29-52)^{\star}\end{array}$ & $\begin{array}{c}31 \\
(22-42) \\
\end{array}$ & $\begin{array}{c}46 \\
(36-58) \\
\end{array}$ & $\begin{array}{c}36 \\
(26-56) \\
\end{array}$ \\
\hline Overweight & $\begin{array}{c}47 \\
(35-64)^{*}\end{array}$ & $\begin{array}{c}54 \\
(44-65)^{\star} \\
\end{array}$ & $41(31-55)$ & $35(26-48)^{*}$ & $63(47-82)^{\star}$ & $\begin{array}{c}31 \\
(21-43)^{*} \\
\end{array}$ & $\begin{array}{c}24 \\
(15-39) \\
\end{array}$ & $\begin{array}{c}40 \\
(32-51)^{\star}\end{array}$ & $\begin{array}{c}37 \\
(28-49) \\
\end{array}$ & $\begin{array}{c}48 \\
(38-61) \\
\end{array}$ & $\begin{array}{c}44 \\
(31-54) \\
\end{array}$ \\
\hline Obesity & $\begin{array}{c}42 \\
(33-57)^{*}\end{array}$ & $\begin{array}{c}49 \\
(39-60)^{*}\end{array}$ & $38(27-53)$ & $30(22-43)^{*}$ & $57(42-74)^{\star}$ & $\begin{array}{c}28 \\
(18-39)^{*}\end{array}$ & $\begin{array}{c}25 \\
(15-33) \\
\end{array}$ & $\begin{array}{c}37 \\
(29-46)^{\star}\end{array}$ & $\begin{array}{c}36 \\
(26-46)\end{array}$ & $\begin{array}{c}45 \\
(36-56) \\
\end{array}$ & $\begin{array}{c}42 \\
(33-51) \\
\end{array}$ \\
\hline \multicolumn{12}{|l|}{ Smoking: } \\
\hline Never & $\begin{array}{c}44 \\
(34-59)^{*} \\
\end{array}$ & $\begin{array}{c}52 \\
(42-64)^{*} \\
\end{array}$ & $39(29-53)^{*}$ & $32(22-46)^{*}$ & $61(46-79)^{*}$ & $\begin{array}{c}30 \\
(21-42)^{*} \\
\end{array}$ & $\begin{array}{c}25 \\
(14-39)^{*} \\
\end{array}$ & $\begin{array}{c}40 \\
(31-52)^{*}\end{array}$ & $\begin{array}{c}34 \\
(26-44)^{*}\end{array}$ & $\begin{array}{c}46 \\
(37-59)^{*}\end{array}$ & $\begin{array}{c}43 \\
(31-52)^{*} \\
\end{array}$ \\
\hline Former & $\begin{array}{c}50 \\
(37-68)^{*} \\
\end{array}$ & $\begin{array}{c}55 \\
(44-66)^{*} \\
\end{array}$ & $48(34-61)^{\star}$ & $38(28-52)^{\star}$ & $66(49-85)^{*}$ & $\begin{array}{c}31 \\
(20-43)^{*} \\
\end{array}$ & $\begin{array}{c}27 \\
(17-38)^{*} \\
\end{array}$ & $\begin{array}{c}39 \\
(30-50)^{*}\end{array}$ & $\begin{array}{c}39 \\
(30-50)^{*}\end{array}$ & $\begin{array}{c}48 \\
(38-61)^{*}\end{array}$ & $\begin{array}{c}46 \\
(35-57)^{*} \\
\end{array}$ \\
\hline Current & $\begin{array}{c}41 \\
(31-58)^{*} \\
\end{array}$ & Excluded & $37(26-51)^{\star}$ & $31(22-46)^{*}$ & $56(41-78)^{*}$ & $\begin{array}{c}26 \\
(18-38)^{*} \\
\end{array}$ & $\begin{array}{c}20 \\
(15-29)^{*}\end{array}$ & $\begin{array}{c}37 \\
(29-46)^{\star}\end{array}$ & $\begin{array}{c}32 \\
(22-45)^{*}\end{array}$ & $\begin{array}{c}43 \\
(33-54)^{\star}\end{array}$ & $\begin{array}{c}35 \\
(26-49)^{*} \\
\end{array}$ \\
\hline \multicolumn{12}{|l|}{$\begin{array}{l}\text { Vigorous } \\
\text { physical activity: }\end{array}$} \\
\hline No & $\begin{array}{c}44 \\
(33-58)^{\star}\end{array}$ & $\begin{array}{c}52 \\
(42-64)^{*}\end{array}$ & $37(28-51)^{*}$ & $32(23-46)^{*}$ & $58(43-77)^{\star}$ & $\begin{array}{c}28 \\
(18-40)^{*}\end{array}$ & $\begin{array}{c}22 \\
(14-33) \\
\end{array}$ & $\begin{array}{c}36 \\
(28-45)^{\star}\end{array}$ & $\begin{array}{c}35 \\
(26-43)\end{array}$ & $\begin{array}{c}45 \\
(35-58)^{\star}\end{array}$ & $\begin{array}{c}39 \\
(30-51)^{*}\end{array}$ \\
\hline Yes & $\begin{array}{c}49 \\
(36-66)^{\star}\end{array}$ & $\begin{array}{c}57 \\
(46-68)^{\star}\end{array}$ & $48(35-64)^{*}$ & $44(34-53)^{*}$ & $67(50-86)^{*}$ & $\begin{array}{c}30 \\
(20-42)^{\star}\end{array}$ & $\begin{array}{c}25 \\
(16-38)\end{array}$ & $\begin{array}{c}40 \\
(31-51)^{\star}\end{array}$ & $\begin{array}{c}35 \\
(25-49)\end{array}$ & $\begin{array}{c}47 \\
(37-59)^{*}\end{array}$ & $\begin{array}{c}45 \\
(32-57)^{\star}\end{array}$ \\
\hline \multicolumn{12}{|l|}{$\begin{array}{l}\text { History of } \\
\text { diabetes: }\end{array}$} \\
\hline No & $\begin{array}{c}46 \\
(35-62)^{\star}\end{array}$ & $\begin{array}{c}54 \\
(43-65)^{*}\end{array}$ & $41(30-55)$ & $32(23-46)$ & $64(47-83)^{*}$ & $\begin{array}{c}30 \\
(20-42)\end{array}$ & $\begin{array}{c}25 \\
(17-36)^{*}\end{array}$ & $\begin{array}{c}39 \\
(30-50)\end{array}$ & $\begin{array}{c}35 \\
(25-47)\end{array}$ & $\begin{array}{c}46 \\
(37-59)^{*}\end{array}$ & $\begin{array}{c}44 \\
(31-55)^{\star}\end{array}$ \\
\hline Yes & $\begin{array}{c}44 \\
(32-59)^{*}\end{array}$ & $\begin{array}{c}51 \\
(42-60)^{*}\end{array}$ & $40(30-52)$ & $33(25-42)$ & $55(41-72)^{\star}$ & $\begin{array}{c}29 \\
(18-39)\end{array}$ & $\begin{array}{c}19 \\
(12-33)^{*}\end{array}$ & $\begin{array}{c}39 \\
(29-48)\end{array}$ & $\begin{array}{c}37 \\
(27-47)\end{array}$ & $\begin{array}{c}40 \\
(33-50)^{*}\end{array}$ & $\begin{array}{c}38 \\
(29-43)^{\star}\end{array}$ \\
\hline
\end{tabular}


Table 2 (continued)

\begin{tabular}{|c|c|c|c|c|c|c|c|c|c|c|c|}
\hline \multirow[b]{3}{*}{ Characteristic } & \multicolumn{11}{|c|}{ Median (interquartile range) concentration of $25(\mathrm{OH}) \mathrm{D}(\mathrm{nmol} / \mathrm{L})^{*}$} \\
\hline & \multirow[b]{2}{*}{ ESTHER } & \multirow[b]{2}{*}{ Tromsø } & \multirow[b]{2}{*}{ MONICA-KORA } & \multirow[b]{2}{*}{ SENECA $\dagger$} & \multirow[b]{2}{*}{ NHANES $\ddagger$} & \multicolumn{2}{|c|}{ HAPIEE Czech Rep } & \multicolumn{2}{|c|}{ HAPIEE Poland } & \multicolumn{2}{|c|}{ HAPIEE Lithuania } \\
\hline & & & & & & Controls & Cases & Controls & Cases & Controls & Cases \\
\hline \multicolumn{12}{|l|}{$\begin{array}{l}\text { History of } \\
\text { hypertension: }\end{array}$} \\
\hline No & $\begin{array}{c}47 \\
(35-63)^{\star}\end{array}$ & $\begin{array}{c}52 \\
(41-64)^{\star}\end{array}$ & $42(31-57)^{*}$ & $33(23-47)$ & $64(47-83)^{*}$ & $\begin{array}{c}30 \\
(19-43)\end{array}$ & $\begin{array}{c}24 \\
(16-35)\end{array}$ & $\begin{array}{c}39 \\
(30-49)\end{array}$ & $\begin{array}{c}35 \\
(25-49)\end{array}$ & $\begin{array}{c}46 \\
(36-59)\end{array}$ & $\begin{array}{c}40 \\
(30-56)\end{array}$ \\
\hline Yes & $\begin{array}{c}44 \\
(34-60)^{\star}\end{array}$ & $\begin{array}{c}54 \\
(44-66)^{\star}\end{array}$ & $38(28-53)^{*}$ & $32(22-44)$ & $60(44-80)^{*}$ & $\begin{array}{c}29 \\
(20-41)\end{array}$ & $\begin{array}{c}24 \\
(15-36)\end{array}$ & $\begin{array}{c}39 \\
(30-50)\end{array}$ & $\begin{array}{c}35 \\
(26-46)\end{array}$ & $\begin{array}{c}46 \\
(37-58)\end{array}$ & $\begin{array}{c}42 \\
(31-52)\end{array}$ \\
\hline \multicolumn{12}{|l|}{ History of CVD: } \\
\hline No & $46(34-62)$ & $\begin{array}{c}54 \\
(43-65)\end{array}$ & $41(29-55)$ & $32(23-46)$ & $62(46-81)$ & $\begin{array}{c}30 \\
(20-42)\end{array}$ & $\begin{array}{c}24 \\
(16-36)\end{array}$ & $\begin{array}{c}39 \\
(30-50)\end{array}$ & $\begin{array}{c}36 \\
(26-49)\end{array}$ & $\begin{array}{c}45 \\
(36-59)^{*}\end{array}$ & $\begin{array}{c}42 \\
(31-54)\end{array}$ \\
\hline Yes & $46(34-64)$ & $\begin{array}{c}54 \\
(44-67) \\
\end{array}$ & $41(33-54)$ & $34(22-46)$ & $60(44-81)$ & $\begin{array}{c}29 \\
(20-40)\end{array}$ & $\begin{array}{c}23 \\
(14-30) \\
\end{array}$ & $\begin{array}{c}37 \\
(28-49) \\
\end{array}$ & $\begin{array}{c}33 \\
(25-42) \\
\end{array}$ & $\begin{array}{c}48 \\
(40-61)^{*}\end{array}$ & $\begin{array}{c}41 \\
(29-50) \\
\end{array}$ \\
\hline \multicolumn{12}{|l|}{$\begin{array}{l}\text { History of } \\
\text { cancer: }\end{array}$} \\
\hline No & $46(34-62)$ & $\begin{array}{c}54 \\
(43-65)^{*}\end{array}$ & $43(32-57)$ & $32(23-46)$ & $61(45-81)^{\star}$ & $\begin{array}{c}30 \\
(20-42) \\
\end{array}$ & $\begin{array}{c}24 \\
(16-36) \\
\end{array}$ & $\begin{array}{c}39 \\
(30-50)\end{array}$ & $\begin{array}{c}35 \\
(25-47)\end{array}$ & $\begin{array}{c}46 \\
(37-59)\end{array}$ & $\begin{array}{c}42 \\
(31-53)\end{array}$ \\
\hline Yes & $44(33-60)$ & $\begin{array}{c}52 \\
(42-63)^{*}\end{array}$ & $33(23-57)$ & $34(14-40)$ & $65(47-83)^{\star}$ & $\begin{array}{c}32 \\
(20-43)\end{array}$ & $\begin{array}{c}21 \\
(12-28)\end{array}$ & $\begin{array}{c}39 \\
(32-46)\end{array}$ & $\begin{array}{c}34 \\
(26-47)\end{array}$ & $\begin{array}{c}45 \\
(37-59)\end{array}$ & $\begin{array}{c}43 \\
(29-55)\end{array}$ \\
\hline
\end{tabular}

25(OH)D=25-hydroxyvitamin D; BMI=body mass index; CVD=cardiovascular disease; NA=not applicable.

*Statistically significant $(\mathrm{P}<0.05)$ by Wilcoxon rank-sum test.

†Regional differences in SENECA: median (interquartile range) 25(OH)D concentration (nmol/L); north Europe 39 (28-49), central Europe 34 (26-50), south Europe 26 (18-34).

‡Regional differences in NHANES: median (interquartile range) 25(OH)D (nmol/L); northeast 61 (47-82), mid-west 66 (47-84), south 62 (45-82), west 58 (44-76). Differences by race and ethnicity: non-Hispanic white 70 (54-89), non-Hispanic black 48 (37-65), Mexican-American 56 (44-75), other (mainly Asian) 58 (46-78). $\S$ Winter=December-February; Spring=March-May; Summer=June-August; Autumn=September-November.

TDefinition of categories of education by highest level of full-time education or years of full-time educations: low (primary school or less or $\leq 9$ years), medium (more than primary school but less than college or university or 10-12 years), high (college or university or $\geq 13$ years).

${ }^{* *}$ Definition of categories of weight by World Health Organization BMI categories: normal or underweight $\left(<25 \mathrm{~kg} / \mathrm{m}^{2}\right)$, overweight $(25-<30)$; obesity $(\geq 30)$. 


\section{Figures}

\begin{tabular}{|c|c|c|c|c|c|}
\hline \multirow[b]{2}{*}{ Study } & \multicolumn{2}{|c|}{ Sample size } & \multirow[b]{2}{*}{$\begin{array}{c}\text { Follow-up } \\
\text { period (years) }\end{array}$} & \multirow[b]{2}{*}{$\begin{array}{c}\text { Risk ratio } \\
(95 \% \mathrm{Cl})\end{array}$} & \multirow[b]{2}{*}{$\begin{array}{c}\text { Risk ratio } \\
(95 \% \mathrm{Cl})\end{array}$} \\
\hline & Total & Cases & & & \\
\hline ESTHER & 9083 & 1338 & 11.0 & & 1.51 (1.26 to 1.80$)$ \\
\hline Troms $\emptyset$ & 4406 & 1141 & 14.2 & & 1.21 (1.00 to 1.46$)$ \\
\hline MONICA-KORA & 939 & 366 & 15.9 & & 1.35 (0.96 to 1.90$)$ \\
\hline SENECA & 661 & 270 & 8.3 & & 2.13 (1.39 to 3.26$)$ \\
\hline HAPIEE CZ & 2029 & 453 & 7.9 & & 2.08 (1.46 to 2.96 ) \\
\hline HAPIEE Pol & 1700 & 411 & 7.0 & & 1.56 (1.09 to 2.24$)$ \\
\hline HAPIEE Lit & 1574 & 368 & 4.2 & & 2.32 (1.59 to 3.38 ) \\
\hline NHANES & 5626 & 2348 & 12.3 & - & 1.42 (1.24 to 1.63$)$ \\
\hline \multirow[t]{2}{*}{ Summary } & 26018 & 6695 & - & & 1.57 (1.36 to 1.81$)$ \\
\hline & & & 0.5 & 2 & \\
\hline
\end{tabular}

Fig 1 Risk ratios of all-cause mortality for bottom versus top quintiles of 25-hydroxyvitamin D concentration in eight cohorts (meta-analysis of individual participant data) 


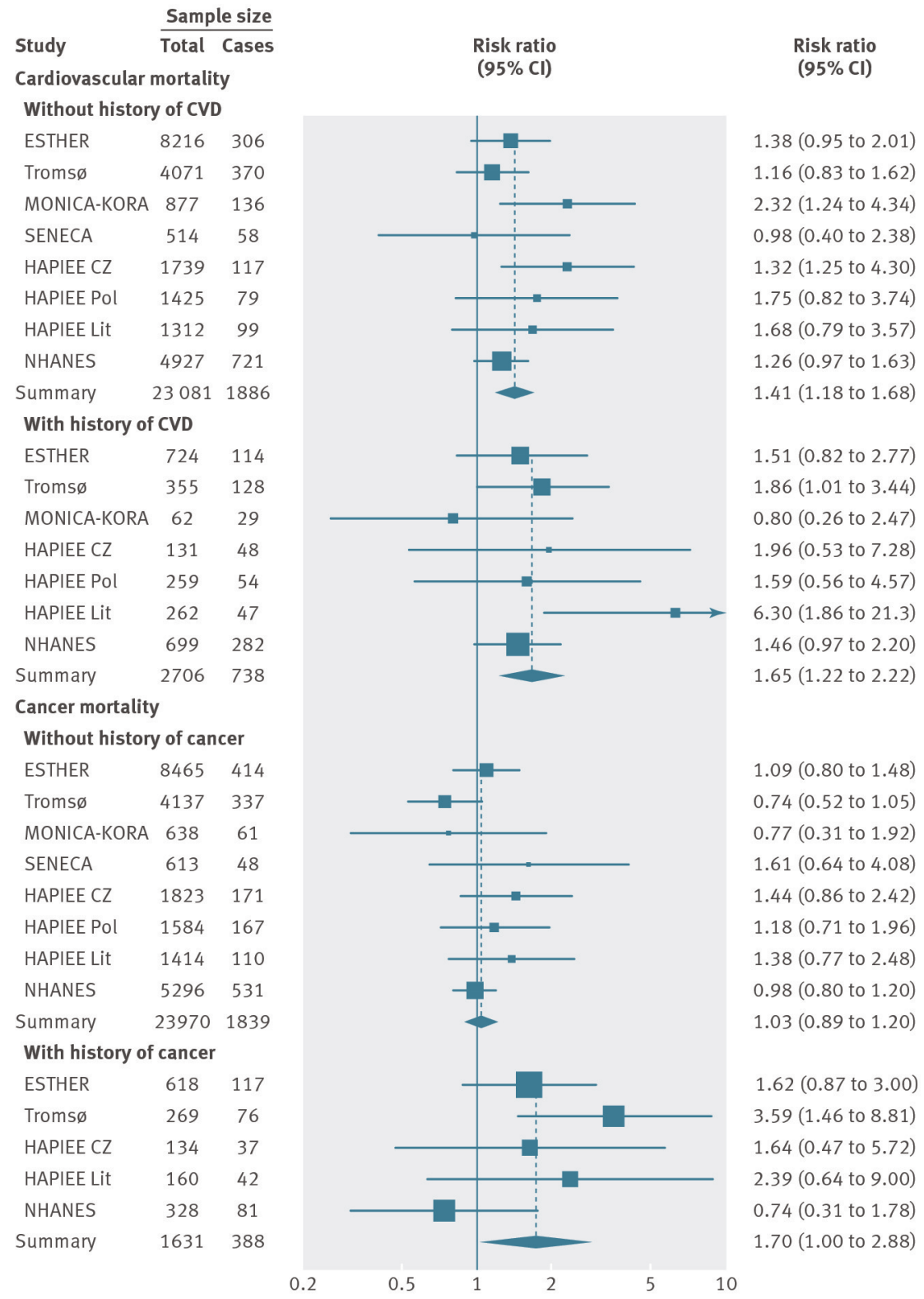

Fig 2 Risk ratios of cardiovascular mortality in subjects with and without a history of cardiovascular disease (top panel) and of cancer mortality in subjects with and without a history of cancer (bottom panel) for bottom versus top quintiles of 25-hydroxyvitamin D concentration in eight cohorts (meta-analysis of individual participant data) 


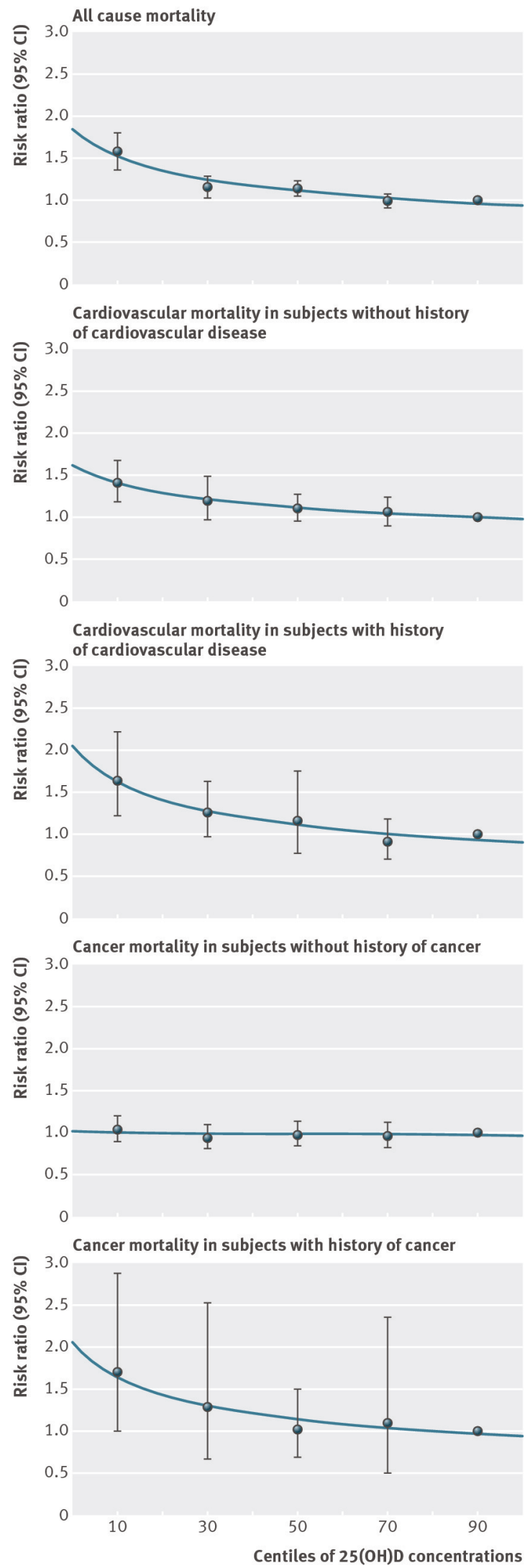

Fig 3 Dose-response trend of pooled effect estimates for the comparison of 25-hydroxyvitamin D quintiles (top quintile as reference) with respect to mortality outcomes 


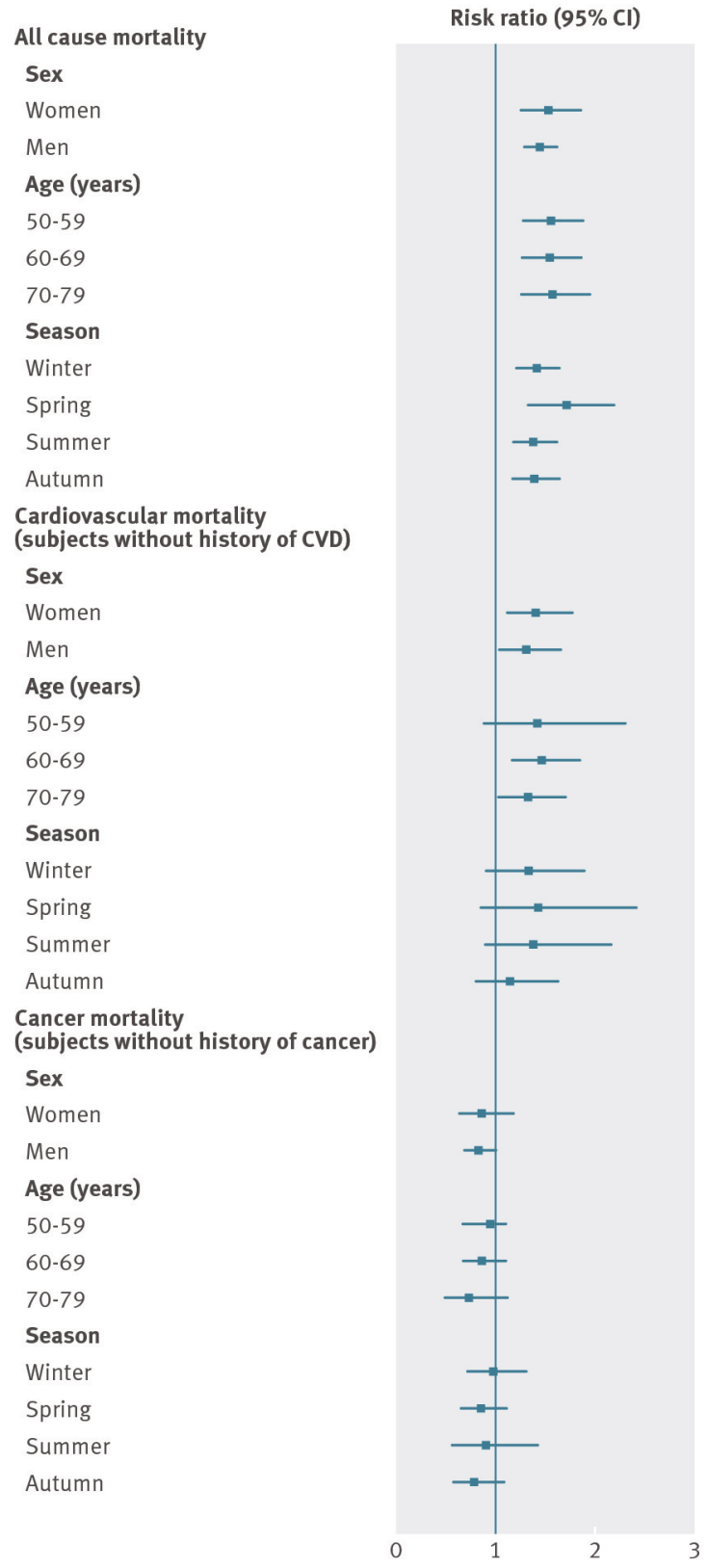

Fig 4 Sex-, age-, and season-specific pooled effect estimates for bottom versus top quintiles of 25-hydroxyvitamin D concentration with respect to all-cause mortality, cardiovascular mortality in subjects without a history of cardiovascular disease (CVD), and cancer mortality in subjects without a history of cancer 